\title{
Bylaws of the Extended Campus Library Services Section
}

d. note: These are the official bylaws of the

Extended Campus Library Services Section as approved by the membersbip on the Spring 1991 ballot.

\section{Article I. Name}

Section 1. The name of this organization shall be the Extended Campus Library Services Section of the Association of College and Research Libraries, a Division of the American Library Association.

\section{Article II. Object}

Section 1. The primary objectives of the Section shall be to advance extended campus librarianship and to foster and share information on extended campus library services. It shall be the further purpose of this Section to contribute to library service and librarianship through programs, lectures, and publications and to represent extended campus librarians.

\section{Article III. Membership}

Section 1. Any member of the Association of College and Research Libraries may select membership in the Extended Campus Library Services Section. Every personal member of the Section has the right to vote and is eligible to hold office.

\section{Article IV. Officers}

Section 1. Officers. The officers of this Section shall be: chair, vice-chair/chair-elect, immediate past chair, and secretary.

Section 2. Terms of Office. The vice-chair will serve successively for one year as vice-chair, chair, and immediate past chair. The secretary shall serve for two years. All terms of office shall begin at the adjournment of the Annual Conference.

Section 3. Vacancies. Chair and vice-chair/ chair-elect. If the offices of both chair and vicechair become vacant within the same year, the Executive Committee shall designate one of its members to act as chair until a chair is duly elected. At the next election, two candidates shall be elected, one to take the office of chair immediately and to serve for one year, the orher to serve as vice-chair/chair-elect. If the office of vice-chair becomes vacant, two candidates shall be elected at the next election, one to take the office of chair immediately and to serve for one year, the other to serve as vice-chair/ chair-elect.

Secretary. If the office of secretary becomes vacant, a secretary shall be elected at the next election for a two-year term. A member of the Executive Committee shall be appointed by the chair to serve as interim secretary until the election takes place.

\section{Article V. Executive Committee}

Section 1. Compasition. There shall be an Executive Committee consisting of the officers of the Section and two elected members-at-large. In addition the chairs of the standing committees shall serve as voting members. The chair of the Section shall serve as chair of the Executive Committee.

Section 2. Terms of Office. The elected members-at-large serve for two years with one new member elected each year.

Section 3. Vacancies. If a member-at-large resigns, the chair, subject to the approval of the Executive Committee, shall appoint a successor to complete the unexpired term.

Section 4. Meetings. Regular meetings of the Executive Committee shall be held at the time and place of the Annual and Midwinter Conferences of the American Library Association. Special meetings may be called at the discretion of the chair.

Section 5. Duties and Autbority. The Executive Committee shall have general oversight and direction of the affairs of the Section. It shall conduct all business pertaining to the Section, and shall have authority to make decisions for the Section during the period between meetings. 


\section{FITILLY. Ethnie Newspapers \& Whagazines. FULLTEXT.}

Until now, no one had collected the significant body of newspapers and magazines

published by the ethnic and minority press in America. Publications from

African-Americans, Asian-Americans, Hispanics, Jewish-Americans, Native-Americans and many others. Publications representing the ethnic diversity of America.

Publications with important information and perspectives-the other sides of the stories.

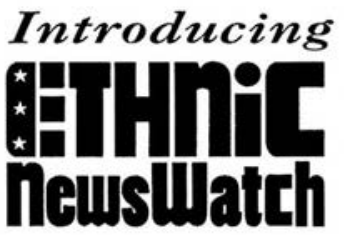

\section{A New Multicultural Database FULL TEXT on CD ROM}

\section{FIRST TIME EVER}

Newspapers and magazines from the ethnic and minority press in America.

- Thousands of articles, editorials and reviews - Full Text

- Every publication full 7 indexed $\bullet$ Fast and easy searching through one comprehensive database

- Searching across ethnic groups • Searching in English or Spanish • Spanish articles in Spanish

Ethnic NewsWatch on CD ROM reflects the changing face of America and fills the need for information for and about a new and expanding multicultural society.

Phone, Fax or Write

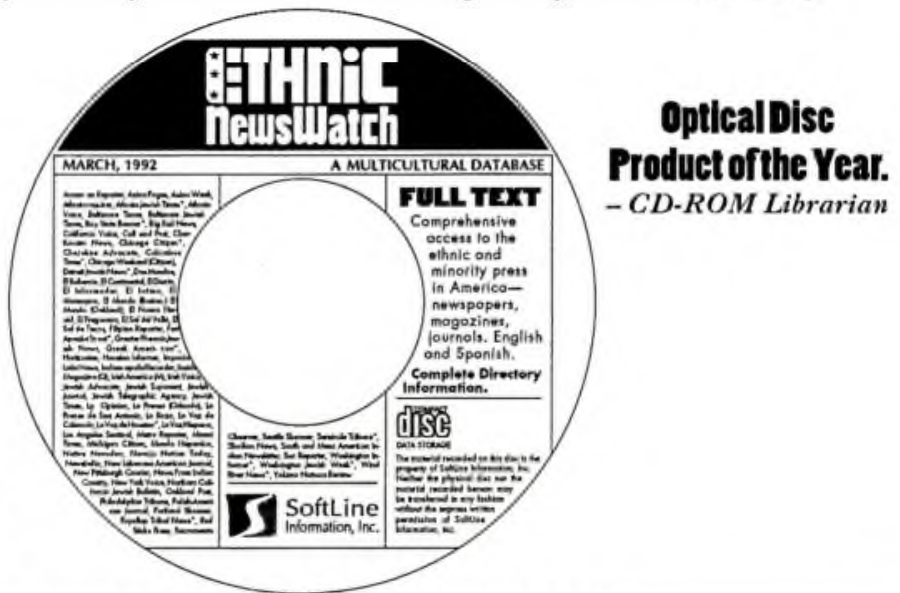

GIARTER SUBSGBPTIOL AVILABL.

SoftLine

Information, inc.

PO Box 16845 Stamford, CT 06905 FAX (203) 968-2370 TEL (203) 968-8878 
Section 6. Quorum. A majority of the members shall constitute a quorum of the Executive Committee.

\section{Article VI. Committees}

Section 1. Autborization and Discontinuance. Committees of the Section as a whole shall be authorized or discontinued by action of the $\mathrm{Ex}^{-}$ ecutive Committee.

Section 2. Standing Committees. Standing Committees may be established to consider matters of the Section that require continuity of attention by the members. When such a committee is established, its charge, name, and size shall be determined. Unless otherwise approved by the Executive Committee, members of standing committees shall be appointed for terms of two years and may be reappointed for a second term. In no case shall a person serve on a committee for more than four consecutive years. Appointments shall be made in such a manner as to provide continuity in membership and allow for broad representation from the membership.

Section 3. Special or Ad boc Committees. Special or ad hoc committees may be established at any time by the chair, with the approval of the Executive Committee, for the performance of a particular assignment. No such committee may be continued beyond three years without review and reapproval by the Executive Committee.

Section 4. Appointment. The vice-chair/ chair-elect of the Section shall appoint committee members to fill the vacancies due to occur during his/her term as chair. The vicechair will name the chair of each committee. Special appointments to fill vacancies on committees may be made by the chair of the Section on the advice of the committee chair.

\section{Article VII. Discussion Groups}

Section 1. Establishment. Any group of ten or more members of the Section interested in discussing common concerns which fall within the objectives of the section may form a discussion group upon written petition from the group and approval by the Executive Committee.

Section 2. Members. Membership in a discussion group shall be open to all members of the Section.

Section 3. Officers. A chair and other officers as appropriate for the discussion group shall be elected by the members of the discussion group.
Section 4. Dissolution. Discussion groups must petition every three years and be approved by the Executive Committee in order to continue meeting. A discussion group may be dissolved at its own request or by the Executive Committee if it becomes inactive or fails to comply with the provisions of this article.

\section{Article VIII. Nominations and Elections}

Section 1. Nominating Committee. The vicechair/chair-elect of the Section shall appoint a Nominating Committee of at least three members who will serve for one year, designating one member as chair. The committee shall choose, in accordance with the deadlines prescribed by the executive director of the Association of College and Research Libraries, a slate of two nominees for each of the offices of vicechair/chair-elect, secretary, and two membersat-large. All nominees must be personal members of the Section and have consented in writing to their candidacy.

Section 2. Statement of Objectives. To assist the membership of the Section in making informed choices, each candidate shall be asked to provide a brief statement of objectives for the Section in time for the statement to be published prior to balloting.

Section 3. Additional Nominees. Additional nominations may be made by petition signed by at least ten members of the Section. Petitions must be filed with the secretary of the Section and the executive director of the Association of College and Research Libraries at least three months prior to the date on which ballots must be mailed. Any such nominees must be personal members of the Section and must submit written consent to stand for election and a statement of objectives.

Section 4. Election. Elections shall be conducted by mail ballot. The candidate receiving the largest number of votes shall be elected and the results reported to the Executive Director of ACRL. In the case of a tie vote, the successful candidate shall be determined by lot.

\section{Article IX. Meetings}

Section 1. Annual Meeting. The annual meeting of the Section shall be held at the time and place of the Annual Conference of the American Library Association.

Section 2. Special Meetings. Other meetings of the Section may be called by the chair with the approval of the Executive Committee. The 
Section, with the approval of the Board of Directors of ACRL, may hold closed meetings or joint meetings with other sections.

Section 3. Quorum. Members of the Section present at an annual meeting shall constitute a quorum.

\section{Article X. Amendments}

Section 1. Proposals. Amendments to the Bylaws may be proposed by any commintee of the Section or by petition signed by ten members of the Section. Proposed amendments shall be presented in writing to the chair.
Section 2. Procedure. Proposed amendments must be approved by the Executive Committee of the Section and by the Board of Directors of ACRL, following review by the ACRL Constitution and Bylaws Committee before membership can be notified of the proposed revisions.

Section 3. Voting. The Bylaws may be amended by a two-thirds vote of the members present and voting at an annual meeting of the Section or by mail vote approved by two-thirds of the members voting. Notice of the proposed changes must be published not less than one month before final consideration.

\section{Lethers}

To the Editor:

Thomas G. Reid Jr.'s vitriolic letter (March 1992) reveals the purblindness of his reactionary ilk. It is he who is either confused or hypocritical on the issue of Al.A's position on the gag rule imposed by the Rust decision.

Reid conflates simply making referrals or providing information-what both librarians and health professionals do-with nefarious advocacy. Rust did not just "stop [federal employees] from saying one word in favor of abortion," as Reid claims. It prohibited anyone receiving Title $\mathrm{X}$ funding from providing neutral information about it, even from pointing at the listings in the yellow pages.

For Reid's strained analogies to make sense, it would be illegal for staff in federally supported libraries to refer readers to books that contained racial slurs (Huck Finn) or sexual harassment (Clarissa), or to communist or anarchist tracts, or to publications of the Hemlock Society. Talk about PC! . . .

Moreover, Rust went further than a simple prohibition: it prescribed a unique, fixed statement that health professionals must utter if queried about abortion. This is more than censorship-it is political ventriloquism. Were such a positive injunction extended to the realm of political economy, we would be forced to mouth words devised by the Heritage Foundation and approved by presidential appointees.

All of this is precisely why it was legitimate and even necessary for the American Library Association to intervene in the Rust case on the side of freedom of expression-even for federally funded operations.-Jeffry Larson, bibliographer, Yale University

\section{To the Editor:}

I was glad to see the favorable account, written by Gail Junion-Metz and Ray E. Metz, of ACRL-New York's 1990 symposium. However, I was surprised by the shallow interpretation of my talk and astonished by the statement that I called upon publishers to practice "bibliographic birth control." This is a phrase I would never use seriously and expresses a concept I would never support. I was ridiculing those who would advocate such an unlikely, simplistic, and counter-productive "solution" to the problem of information overload-Mary Biggs, Director of Libraries, Mercy College

\section{The authors respond:}

The information on the New York meeting which we used in our CERL News article was obtained from the Winter 1991 issue of the Metropolitan New York ACRL Chapter Newsletter. The article titled "Highlights of Access to Excess? Issues of the Information Explosion" contains a two-paragraph description of Ms. Biggs's comments. The following is from that description: "While publishers should practice voluntary 'bibliographic birth control,' librarians must help sift 'essence from excess.' If in our attempt to ensure that more librarians learned about this important program, we inadvertently misinterpreted the speaker's intent, we're sorry.-Ray E. Metz, Case Western Reserve University, and Gail Junion-Metz, Cleveland State University 